\title{
A DINAMICIDADE DO DIREITO JURISPRUDENCIAL E O PAPEL DOS EMBARGOS DE DECLARAÇÃO COMO MECANISMO DE INTEGRAÇÃO DO SISTEMA $^{1}$
}

\section{THE DYNAMICS OF THE PRECEDENTS AND THE ROLE OF THE "EMBARGOS DE DECLARAÇÃO” AS AN INSTRUMENT TO THE INTEGRATION OF THE SYSTEM OF PRECEDENTS}

Ravi Peixoto Doutor em direito processual pela UERJ. Mestre em Direito pela UFPE. Membro da Associação Norte e Nordeste de Professores de Processo (ANNEP), do Centro de Estudos Avançados de Processo (CEAPRO), da Associação Brasileira de Direito Processual (ABDPRO) e do Instituto Brasileiro de Direito Processual (IBDP). Procurador do Município do Recife. Advogado. E-mail: ravipeixoto@gmail.com

RESUMO: O artigo se propõe a repensar o funcionamento dos embargos de declaração em relação às omissões indiretas, nas quais, mesmo sem alegação prévia da parte, o sistema permite a utilização dessa espécie recursal no sistema de precedentes. Propõe-se uma interpretação ampliativa do art. 1.022, parágrafo único, I, do CPC, para permitir a utilização dos embargos declaratórios para além da previsão expressa do texto normativo.

PALAVRAS-CHAVE: Embargos de declaração. Omissão indireta. Precedentes obrigatórios. Interpretação ampliativa.

ABSTRACT: The article proposes to rethink the possibilities of the "embargos de declaração" in reference to the indirect omissions, where the law allows using this recourse the allegation of omissions in relation to a precedent. The proposal it to allow an ampliative

\footnotetext{
${ }^{1}$ Artigo recebido em 25/07/2020 e aprovado em 09/08/2020.
} 
interpretations of the article 1.022, p.ú., I, of the Civil Procedure Code to allow the use of the embargos de declaração beyond the literal interpretation of the statute.

KEY WORDS: Embargos de declaração. Indirect omission. Stares decisis. Ampliativa interpretation

\section{Introdução}

O direito brasileiro, durante as últimas décadas, em especial no período após a aprovação do CPC de 2015, passa por uma fase de valorização dos precedentes enquanto instrumento de promoção do princípio da segurança jurídica e da igualdade. A partir do momento em que os precedentes deixam de ter eficácia apenas persuasiva para ter eficácia obrigatória, a sua importância no ordenamento jurídico aumenta consideravelmente, pois passam a vincular por sua autoridade e não por suas razões, limitando a liberdade decisória dos julgadores.

É inegável que, se os precedentes possuem eficácia obrigatória, impõe ao juiz, no momento de julgar, que eles sejam levados em consideração, por decorrência do dever de autorreferência. Essa mesma obrigatoriedade também ocorre com o surgimento de um precedente vinculante, bem como a superação de um precedente obrigatório no decorrer de um processo, que pode ser tido como o surgimento de um direito novo, que, ao contrário do direito legislado, incide e pode ser alterado após a ocorrência do fato jurídico.

O processo brasileiro, infelizmente, é demorado ${ }^{2}$ e ao mesmo tempo, a jurisprudência pátria ainda não conseguiu se adequar aos deveres impostos pelo art. 926 do CPC. Assim, é bastante possível que o surgimento e alterações de precedentes possam ocorrer durante o trâmite de um processo.

Muito embora o art. 1.022, parágrafo único, I, do CPC, permita que se utilize dos embargos declaratórios para forçar o reconhecimento de algumas espécies de precedentes obrigatórios, trata-se de uma previsão normativa tímida e, de certa forma,

\footnotetext{
${ }^{2}$ Por exemplo, o tempo médio apenas para a prolação da sentença em 2018 era de 2 anos e 2 meses, sem contar com o tempo para as fases recursais. (Justiça em número 2019. Disponível em: https://www.cnj.jus.br/wpcontent/uploads/conteudo/arquivo/2019/08/8ee6903750bb4361b5d0d1932ec6632e.pdf).
} 
contrária a outros dispositivos do $\mathrm{CPC}$, como será devidamente delimitado no texto. $\mathrm{O}$ objetivo deste artigo é o de refletir sobre os mecanismos que permitem a imposição da análise, pelo julgador, de precedentes obrigatórios, propondo uma interpretação ampliativa das hipóteses de cabimentos dos embargos de declaração.

\section{A importância dos precedentes na dinâmica jurídica}

O direito brasileiro vem passando por um período de fortalecimento do papel dos precedentes no contexto decisório, que possui como momento principal a inserção do art. 927 do CPC, que estabelece um rol de precedentes obrigatórios. Ao inserir uma série de decisões de caráter obrigatório, a legislação está impondo que os juízes vinculados a esses precedentes os utilizem como razão de decidir nos seus casos concretos. Os precedentes obrigatórios concretizam os diversos textos normativos, esclarecendo qual deve ser a norma a ser aplicada por parte do Poder Judiciário.

Os precedentes, ao contrário dos textos normativos são dotados de maior dinamicidade, sendo alterados, no Brasil, com certa frequência, fazendo com que o direito aplicável ao caso concreto possa variar durante o próprio tempo do trâmite do processo.

Além disso, a eficácia temporal dos precedentes é diversa da que rege a legislação. No geral, a legislação tem por base a regra da irretroatividade (art. $5^{\circ}$, XXXVI, CFRB), portanto, o fato jurídico é regido pelos textos normativos em vigor ao tempo de sua ocorrência. Ocorrendo a edição de legislação que estabelece uma determinada gratificação aos servidores públicos em maio de 2017, se uma determinada categoria almeja discutir se aquela gratificação a ela se aplica, não importam as legislações editadas posteriormente.

Por outro lado, do ponto de vista dos precedentes, o direito daquela categoria ao recebimento da gratificação pode variar no decorrer do tempo do processo, pois esse direito pode ser reconhecido por precedente obrigatório ou mesmo podia, antes, ter sido reconhecido por precedente obrigatório, passando eventualmente a ser superado com eficácia retroativa. Isso significa que o tempo do precedente é diferente do tempo da legislação, pois ele tem eficácia retroativa, abrangendo fatos que ocorrem antes da sua própria existência. 
Tanto pela dinamicidade quanto pela sua eficácia temporal, é importante que o ordenamento jurídico possua mecanismos que incentivem a observância dos precedentes obrigatórios por parte dos juízes e que permitam às partes, ao menos, o poder de alegar a ausência de análise de um precedente obrigatório.

Por exemplo, o art. 493 do CPC possui uma imposição para que, caso, após a propositura da ação, surja algum fato constitutivo, modificativo ou extintivo do direito que tenha aptidão para influir no julgamento do mérito, "caberá ao juiz tomá-lo em consideração", seja de ofício ou a requerimento da parte, no momento de proferir a decisão. A lógica por trás do texto normativo é a de que as decisões devem ser atuais, ou seja, que reflitam o momento em que são proferidas. ${ }^{3}$

Importa destacar, no que se refere ao art. 493 do CPC, que se trata de um comando ao juiz, sendo verdadeira obrigação judicial o conhecimento do fato superveniente, seja de ofício ou a partir de alegação das partes.

Ocorre que o art. 493 não faz referência a direitos supervenientes. A alegação de direitos supervenientes apenas aparece no art. 342, I, do CPC, que permite ao réu a alegação de direito superveniente. De acordo com a doutrina, esse texto normativo deve ser interpretado de forma ampliativa no sentido de também permitir ao autor a alegação do direito superveniente. ${ }^{4}$

Como uma forma de complementar o raciocínio do art. 342, I, do CPC, quando se fala em direito superveniente, deve se incluir não só a alegação de nova legislação novo, mas, também de precedentes, em especial de precedentes obrigatórios, que consolidam a norma a ser extraída dos textos normativos. O tema será retomado nesse artigo, mas é importante ressalvar que, uma vez que o texto e a norma não se confundem, os precedentes constituem uma forma de densificar as normas que podem ser desenvolvidas dos textos legais. Portanto, as partes podem alegar texto normativo novo e novas interpretações normativas, por óbvio, sempre respeitando os limites da retroatividade de cada uma delas.

De toda forma, mesmo com uma interpretação ampliativa, tem-se uma situação curiosa: enquanto, de acordo com o art. 493 do CPC, há obrigatoriedade do juízo em

\footnotetext{
${ }^{3}$ CUNHA, Leonardo Carneiro da. Comentários ao art. 493. In: DIDIER JR., Fredie; TALAMINI, Eduardo; WAMBIER, Teresa Arruda Alvim; DANTAS, Bruno (coords). Breves comentários ao Novo Código de Processo Civil. São Paulo: RT, 2015, p. 1242.

${ }^{4}$ Idem, ibidem, p. 1245.
} 
conhecer fatos supervenientes, há apenas uma autorização da legislação no art. 342, I, do CPC para que as partes aleguem direitos supervenientes. Em outros termos, há um regime diferente para fatos e direitos supervenientes, que chega a conflitar com a visão tradicional de que ao juiz cabe conhecer o direito (iura novit curia) e às partes a alegação dos fatos ( $d a$ mihi factum, dabo tibi ius). A diferenciação no tratamento do direito e do fato superveniente tem consequências, como se verá, no regime recursal, afinal, se uma categoria é uma simples autorização de alegação da parte, uma decisão que não a leva em consideração de ofício não está omissa. Por outro lado, uma decisão que não leva em consideração uma questão que deve ser conhecida de ofício pelo juízo é omissa.

\section{Os embargos de declaração e a omissão decorrente da ausência de análise} de precedente obrigatório: uma primeira aproximação

De acordo com o art. 1.022, II, do CPC/2015, será possível a utilização dessa modalidade recursal com o objetivo de "suprir omissão de ponto ou questão sobre o qual devia se pronunciar o órgão jurisdicional de ofício ou a requerimento".

Acerca dessa hipótese de cabimento recursal, devem ser realizados alguns apontamentos. A omissão pode ser dividida da seguinte forma: a) omissão ontológica, quando a decisão possuir fundamento e dispositivo, mas não abordar algum ponto relevante, ou seja, há uma incompletude no corpo da fundamentação ou do dispositivo pela não abordagem de alguma questão importante e b) omissão relacional, ocorrida quando o ponto relevante for tratado de forma parcial, havendo a correspondência formal à direção adotada. Pode ser identificado quando há fundamentação sobre determinada questão, mas é ausente a sua parte dispositiva e vice-versa. ${ }^{5}$

Inserida na omissão ontológica, ainda é possível vislumbrar mais duas hipóteses: a) omissão direta, quando o magistrado não se manifestar sobre alguma questão relevante suscitada por uma das partes e b) omissão indireta, caso em que o órgão judicial não se manifesta sobre "questão que, a despeito de não ter sido suscitada pelos interessados, poderia

\footnotetext{
${ }^{5}$ MAZZEI, Rodrigo. Embargos de declaração e a omissão indireta (matérias que devem ser resolvidas de ofício, independentemente de arguição prévia pelo interessado). Revista Forense. Rio de Janeiro: Forense, v. 399, set./out.-2008, p. 170; MIRANDA, Francisco Cavalcanti Pontes de. Comentários ao código de processo civil. $3^{\text {a }}$ ed. Rio de Janeiro: Forense, 2000, t. VII, p. 332-333.
} 
(leia-se aqui: deveria) ter sido resolvida de ofício pelo julgador". ${ }^{6}$ Afinal, o cabimento dos embargos de declaração abrange não somente as hipóteses de uma omissão relacionada a um requerimento expresso das partes, mas também às hipóteses em que houve o descumprimento do dever de decidir uma determinada matéria, mesmo que esta não tenha sido requerida/alegada.

Em geral, acerca da omissão indireta, a doutrina insere, para termos de cabimento dos embargos de declaração, as questões de ordem pública. ${ }^{7}$ Inseridos nessa categoria, é possível mencionar os pressupostos e requisitos processuais ${ }^{8}$ e as nulidades processuais.

Ocorre que a omissão indireta não abrange apenas as questões de ordem pública. Várias outras matérias são incluídas como omissões indiretas, por serem indicadas como um dever do magistrado de conhecê-las, a despeito de não serem classificadas como questões de ordem pública. ${ }^{9}{ }^{10}$ Dentre outros exemplos, menciona a doutrina a aplicação de juros e correção monetária (art. 322, §1 $\left.{ }^{\circ}, \mathrm{CPC} / 2015\right)$, honorários de advogado (art. 85, CPC/2015), c) fato superveniente (art. 493, CPC/2015), d) fixação de multa diária ou medidas de apoio (art. 497, CPC/2015). ${ }^{11}$ Ressaltamos a questão específica dos fatos supervenientes, em que,

\footnotetext{
${ }^{6}$ MAZZEI, Rodrigo. Embargos de declaração e a omissão indireta (matérias que devem ser resolvidas de ofício, independentemente de arguição prévia pelo interessado)... cit., p. 173.

${ }^{7}$ MOREIRA, José Carlos Barbosa. Comentários ao código de processo civil. 14 ${ }^{\mathrm{a}}$ ed. Rio de Janeiro: Forense, 2008, v. V, p. 553; WAMBIER, Teresa Arruda Alvim. Omissão judicial e embargos de declaração. São Paulo: RT, 2005, p. 67-77; CUNHA, Leonardo Carneiro da; DIDIER JR., Fredie. Curso de direito processual civil, $12^{a}$ ed. Salvador: Juspodivm, 2014, v. 3, p. 175-176.

${ }^{8}$ Sob o prisma do CPC/1973, ainda seria viável fazer menção à categoria das condições da ação. No entanto, parte da doutrina afirma que o novo CPC extingue essa categoria, inserindo a possibilidade jurídica do pedido e a legitimação ad causam ordinária como questões de mérito e o interesse de agir e a legitimação extraordinária como requisitos processuais de validade. Nesse sentido: CUNHA, Leonardo Carneiro da. Será o fim da categoria condições da ação? Uma intromissão no debate travado entre Fredie Didier Jr. e Alexandre Freitas Câmara. Revista de Processo, n. 198, ago.-2011; DIDIER JR., Fredie. Será o fim da categoria "condição da ação"? Um elogio ao projeto do novo CPC. Revista de Processo. São Paulo: RT, v. 197, jul.-2011. Em sentido contrário, defendendo a manutenção da categoria, apenas com a exclusão da possibilidade jurídica do pedido e a sua inclusão no interesse de agir, cf.: CÂMARA, Alexandre Freitas. Será o fim da categoria "Condição da Ação"? Uma resposta a Fredie Didier Junior. Revista de Processo, n. 197, jul.-2011.

${ }^{9}$ MAZZEI, Rodrigo. Embargos de declaração e a omissão indireta (matérias que devem ser resolvidas de ofício, independentemente de arguição prévia pelo interessado)... cit., p. 177.

${ }^{10}$ Não se objetiva aqui a realização da valoração da existência ou não da categoria "questões de ordem pública", mas tão somente o de destacar que ela não é necessária para que se admita a cognição de ofício da modulação de efeitos. Para além delas, existem outras hipóteses que exigem cognição de ofício do magistrado. Discutir a sobrevivência ou não do tema questões de ordem pública exigiria um aprofundamento que fugiria aos propósitos desse trabalho. Sobre o tema, cf.: ROCHA, Márcio Oliveira. Sobre a ordem pública processual, essa desconhecida. Salvador: Juspodivm, 2019.

${ }^{11}$ Sobre a questão, com as devidas indicações jurisprudenciais, cf.: MAZZEI, Rodrigo. Embargos de declaração e a omissão indireta (matérias que devem ser resolvidas de ofício, independentemente de arguição prévia pelo interessado)... cit., p. 177-178.
} 
não havendo sua análise de ofício, poderá a parte opor embargos de declaração para impor a cognição pelo juiz sobre o tema. ${ }^{12}$

Quando se parte para a relação entre precedentes obrigatórios e o cabimento dos embargos de declaração, a sua utilização, pelo texto normativo, é bem mais limitada. A primeira hipótese está relacionada com as omissões diretas, uma vez que, de acordo com o art. $489, \S 1^{\circ}$, VI, não se considera fundamentada a decisão que "deixar de seguir enunciado de súmula, jurisprudência ou precedente invocado pela parte, sem demonstrar a existência de distinção no caso em julgamento ou a superação do entendimento". O cabimento dos embargos de declaração sob esse fundamento advém do art. 1.022, parágrafo único, I, segundo o qual é considerada omissa a decisão que "incorra em qualquer das condutas

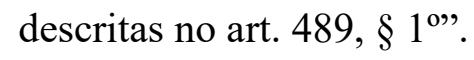

De fato, nesse ponto de vista a autorização para a utilização dos embargos declaratórios é ampla, permitindo, inclusive, a sua utilização para precedentes persuasivos. Essa parece ser a interpretação mais adequada, uma vez que a legislação usa o termo "jurisprudência ou precedente", eis que o termo jurisprudência faz referência um conjunto de entendimentos. Nenhum dos precedentes obrigatórios é formado por um conjunto de precedentes, sendo termo normalmente utilizado para fazer referência a uma linha interpretativa adotada por um determinado órgão jurisdicional, não fazendo necessariamente referência a precedentes obrigatórios.

De toda forma, nessa hipótese, o cabimento dos embargos de declaração decorre de uma violação do princípio do contraditório efetivo e não por uma violação propriamente da observância do precedente. Sob esse ponto de vista, o precedente obrigatório ou persuasivo é um argumento da parte e, não sendo devidamente analisado pelo magistrado, a decisão é omissa.

Ocorre que, quando se parte para a análise do cabimento dos embargos de declaração para a omissão indireta no que se refere aos precedentes, o tratamento normativo é limitado e, até de certa forma, contraditório com outros dispositivos normativos do CPC, a exemplo do art. $493,525, \S \S 12$ a 15 e $535, \S \S 5^{\circ}$ a $8^{\circ}$ e 966, V. É importante que se compreenda, como destacado anteriormente, que os precedentes são dinâmicos - talvez mais

\footnotetext{
${ }^{12}$ CUNHA, Leonardo Carneiro da. Comentários ao art. 493 ... cit., p. 1243; BONDIOLI, Luís Guilherme Aimar. Comentários ao código de processo civil. $2^{\mathrm{a}}$ ed. São Paulo: Saraiva, 2017, v. XX, versão digital, item 142.
} 
do que seria desejável no Brasil -, sendo possível que entendimento obrigatórios surjam no decorrer do processo e mesmo após produzidas todas as peças processuais pelas partes.

Assim, não é difícil vislumbrar hipótese em que foi ultrapassada a fase de razões finais e antes de prolatada a sentença, surge precedente obrigatório novo extremamente relevante para o caso concreto. A mesma coisa pode ocorrer após interposição da apelação e das contrarrazões e ocorrer a superação de precedente obrigatório antes do julgamento pelo tribunal. Por mais que naturalmente as partes possam peticionar informando do surgimento do novo julgamento, é possível que elas apenas tenham conhecimento da sua presença após a decisão. O julgador pode conhecer de ofício do novo precedente, mas pode simplesmente não ter conhecimento de sua existência.

A situação é ainda mais crítica quando o precedente já existia no momento do ajuizamento da ação e o provimento obrigatório não é levado em consideração pelo magistrado no momento da decisão. Afinal, nessa hipótese, sequer se pode afirmar se tratar de direito novo.

Importa destacar que essa não é a uma situação ideal. As partes deveriam diligenciar para levar a conhecimento do juiz precedente obrigatório ${ }^{13}$ e deveria o juiz ter conhecimento de sua existência. Mas os embargos de declaração são espécie recursal que reconhece a falibilidade humana, permitindo, em diversas outras hipóteses, a alegação de omissão de tema que sequer foi suscitado pelas partes devido a sua importância. Por exemplo, é cabível a utilização dos embargos de declaração de forma ampla para a alegação de fatos supervenientes que não tenham sido conhecidos de ofício pelo juiz como uma forma de manter a sentença atual. Curiosamente, o legislador não teve essa mesma preocupação no que se refere ao direito e, mais especificamente, aos precedentes.

Como se infere do art. 1.022, parágrafo único, I, do CPC, é considerada omissa a decisão que "deixe de se manifestar sobre tese firmada em julgamento de casos repetitivos ou em incidente de assunção de competência aplicável ao caso sob julgamento".

\footnotetext{
${ }^{13}$ Ora, por mais que caiba ao juiz o conhecimento do direito, é evidente que as partes são responsáveis por trazer os argumentos favoráveis ao seu caso. O CPC de 2015 atua no sentido de reforçar o dever de justificação judicial, mas que é uma via de mão dupla, também aumentando os deveres de justificação analítica das partes (PEIXOTO, Ravi; DIDIER JR., Fredie. O art. 489, $\S 1^{\circ}$, do CPC e a sua incidência na postulação dos sujeitos processuais - um precedente do STJ. In: ALVIM, Teresa Arruda; CIANCI, Mirna; DELFINO, Lucio . (Org.). Novo CPC aplicado visto por processualistas. São Paulo: Revista dos Tribunais, 2017). A ideia de que o juiz conhece o direito não pode ser usada como uma espécie de desculpa para justificar a falta de responsabilização das partes pelo desenvolvimento dos argumentos jurídicos importantes para o caso.
} 
Assim o fazendo, ignora vários dos precedentes obrigatórios listados no art. 927 do CPC, que possuem até um regime de proteção pela legislação mais forte do que o do incidente de assunção de competência, permitindo ampla utilização da reclamação, como é o caso da súmula vinculante. Analisando de forma comparativa os arts. 927 e 1.022 , parágrafo único, I, não há referência ao cabimento de embargos de declaração quando o juiz deixa de analisar precedentes advindos de "decisões do Supremo Tribunal Federal em controle concentrado de constitucionalidade" (art. 927, I), "enunciados de súmula vinculante" (art. 927, II), “enunciados das súmulas do Supremo Tribunal Federal em matéria constitucional e do Superior Tribunal de Justiça em matéria infraconstitucional” (art. 927, IV) e orientação do plenário ou do órgão especial aos quais estiverem vinculados (art. 927, V). Assim, em tese, é cabível a utilização dos embargos de declaração por omissão única e exclusivamente por violação aos precedentes previstos no art. 927, III.

Essa é, em termos gerais, a amplitude permitida de utilização dos embargos de declaração para a alegação de omissão indireta no que se refere a precedentes obrigatórios no direito positivo brasileiro. Ocorre que, como se verá no próximo item, essa previsão legal está em certa contradição com outros dispositivos normativos que permitem a alegação de não observância de precedentes obrigatórios mesmo após o trânsito em julgado.

\section{A possibilidade de alegação de precedentes obrigatórios após o trânsito}

\section{em julgado}

No direito brasileiro, os principais mecanismos utilizados para impugnar decisões judiciais transitadas em julgado são a ação rescisória (art. 966 e ss. do CPC), a impugnação ao cumprimento de sentença para algumas hipóteses específicas (arts. 525, §§12 a 15 e $535, \S \S 5^{\circ}$ a $8^{\circ}$ do CPC) e a querela nulitatis.

A ação rescisória, para o que interessa ao presente artigo, pode ser utilizada quando há violação manifesta de norma jurídica (art. 966, V, CPC). Relembre-se a lição de que a norma não se confunde com o texto. Ao mesmo tempo em que uma norma pode ser construída pelo sistema, por diversos textos em conjunto, existem também textos sem norma. Como exemplo do primeiro caso, temos o princípio da cooperação no período de vigência 
do CPC/1973; do segundo, o texto constitucional que garante a proteção de Deus. ${ }^{14}$ Caberá ao magistrado, a partir do diálogo com os demais sujeitos processuais, construir a norma aplicável ao caso concreto. No momento em que se parte para um âmbito mais extenso - a teoria dos precedentes - a norma construída nos casos concretos ganha, também, caráter mais amplo. ${ }^{15}$ A ratio decidendi ultrapassa o caso individual, passando a influenciar uma gama incontável de outras situações jurídicas subjetivas. Ela passa a ser a norma viva advinda da interpretação jurisprudencial, sendo observada também como texto a ser interpretado em casos posteriores.

Em sendo a linguagem detentora de imprecisão semântica, a capacidade de previsão do sujeito de direito deve ser dirigida às consequências alternativas atribuíveis pelo direito aos seus atos ou fatos. Trata-se de uma noção que admite uma gama de possibilidades e que visa à proteção de decisões arbitrárias que fujam a qualquer âmbito de possibilidades do ordenamento jurídico. ${ }^{16}$ A distinção entre texto e norma "não pode significar que seja possível atribuir qualquer sentido ao texto" ${ }^{17}$, mesmo que se possa admitir que essa relação se torna cada vez mais dissociada com o crescente aumento da complexidade social. ${ }^{18}$

De acordo com a interpretação da doutrina, uma situação na qual patente a violação a norma jurídica ocorre quando a decisão rescindenda transita em julgado violando

\footnotetext{
14 ÁVILA, Humberto. Teoria dos princípios. $12^{\mathrm{a}}$ ed. São Paulo: Malheiros, 2011, p. 30-31. Importante frisar que não se adota aqui o realismo jurídico. O intérprete está condicionado pelas "mensagens" dos textos normativos. (NEVES, Marcelo. Entre Hidra e Hércules: princípios e regras constitucionais. São Paulo: Martins Fontes, 2013, p. 8-11). Consoante aponta Adriano Soares da Costa, "A significação se contém no texto, mas não apenas nele”. (COSTA, Adriano Soares da. Teoria da incidência da norma jurídica. Belo Horizonte: Del Rey, 2003, p. 7).

15 De certa forma, muito embora não concordemos com sua equiparação a uma atividade legislativa, cf.: KELSEN, Hans. Teoria pura do direito. Trad. de João Baptista Machado. São Paulo: Martins Fontes, 2011, p. 277-283.

16 ÁVILA, Humberto. Segurança jurídica. Malheiros: 2011, p. 148-150; GOMETZ, Gianmarco. La certeza giuridica come prevedibilità. Torino: Giappichelli Editore, 2005, p. 205-208.

${ }^{17}$ STRECK, Lenio Luiz. Diferença (ontológica) entre texto e norma: afastando o fantasma do relativismo. In: TORRES, Heleno Taveira. (coord). Direito e poder: nas instituições e nos valores do público e do privado contemporâneo. Barueri: Manole, 2005, p. 27. De forma semelhante: ADEODATO, João Maurício. A retórica constitucional: sobre tolerância, direitos humanos e outros fundamentos éticos do direito positivo. $2^{a}$ ed. São Paulo: Saraiva, 2010, p. 197-202; MÜLLER, Friedrich. Metodologia do direito constitucional. $4^{\mathrm{a}}$ ed. Trad. de Peter Naumann. São Paulo: RT, 2010, p. 57; NEVES, Marcelo. Entre Hidra e Hércules... cit., p. 10-11; STRECK, Lenio Luiz. O que é isto - decido conforme minha consciência? Porto Alegre: Livraria do Advogado, 2010, p. 25. Como destaca Luis Alberto Warat, ao se criticar o formalismo interpretativo de forma radical, acaba se chegando a uma postulação estereotipada de um vazio significativo dos textos normativos. $\mathrm{E}$ um "vazio que só certos iluminados, ao que parece, poderiam preencher com legitimidade", que seriam os magistrados, incentivando, assim, o subjetivismo nas decisões. (WARAT, Luis Alberto. Introdução geral ao direito - o direito não estudado pela teoria jurídica moderna. Porto Alegre: SAFE, 1997, v. III, p. 149).

18 ADEODATO, João Maurício. A retórica constitucional: sobre tolerância, direitos humanos e outros fundamentos éticos do direito positivo... cit., p. 197.
} 
manifestamente algum precedente obrigatório previsto no art. 927 do CPC. ${ }^{19}$ Uma particularidade importante é a de que não se exige nenhuma espécie de prequestionamento, no que se refere à expressa menção do precedente tido por violado para que seja possível a utilização da ação rescisória. ${ }^{20}$

Situação semelhante pode ser observada no cabimento da impugnação ao cumprimento de sentença previsto no art. $525, \S \S 15$ a 15 do CPC. De acordo com o texto normativo, permite-se que seja reconhecida como inexigível obrigação reconhecida em título executivo judicial fundado em lei ou ato normativo considerado inconstitucional pelo STF, ou baseado em interpretação de ato normativo tido pelo STF como incompatível com a Constituição, em controle de constitucionalidade concentrado ou difuso. A utilização da impugnação ao cumprimento de sentença só pode ter como fundamento precedente existente antes do trânsito em julgado da decisão exequenda.

De forma resumida, é possível o bloqueio da eficácia de decisão baseada em texto normativo tido por inconstitucional pelo STF, seja no controle difuso ou concentrado, desde que a decisão seja tomada pelo plenário. ${ }^{21}$ Essas decisões não precisam ter sido prequestionadas quando ainda em trâmite o processo de conhecimento.

Essas breves considerações sobre o cabimento da alegação de violação de precedente obrigatório como fundamento para a impugnação de decisões transitadas em julgado tiveram por objetivo apontar que o CPC permite, de forma ampla, a alegação de violação a precedente obrigatório não observado pela decisão transitada em julgado. Como se verifica há um nítido descompasso entre a regulação da alegação de omissão por não consideração de precedente obrigatório por meio dos embargos de declaração, quando ainda

\footnotetext{
${ }^{19}$ CUNHA, Leonardo Carneiro da; DIDIER JR., Fredie. Curso de direito processual civil. 16 ed. Salvador: Juspodivm, 2019, v. 3, p. 591. Luiz Guilherme Marinoni e Daniel Mitidiero fazer referência expressa ao cabimento da ação rescisória quando há violação a súmula, vinculante ou não, IAC, IRDR e decisão em incidente de decretação de inconstitucionalidade. (MITIDIERO, Daniel; MARINONI, Luiz Guilherme. Ação rescisória. São Paulo: RT, 2017, p. 210-212).

${ }^{20}$ Como destacam Fredie Didier Jr. e Leonardo Carneiro da Cunha, não é possível exigir o prequestionamento da norma tida por violada. (CUNHA, Leonardo Carneiro da; DIDIER JR., Fredie. Curso de direito processual civil... cit., p. 591-592). No mesmo sentido: CRAMER, Ronaldo. Ação rescisória por violação da norma jurídica. $2^{\mathrm{a}}$ ed. Salvador: Juspodivm, 2012, p. 198-202. Ora, se não é possível exigir sequer o prequestionamento da norma tida por violada, menos ainda pode ser exigido o prequestionamento do precedente tido por violado, que é simplesmente uma interpretação do texto normativo tido por violado.

${ }^{21}$ ROQUE, Andre Vasconcelos. Comentários ao art. 525. In: ROQUE, Andre Vasconcelos; GAJARDONI, Fernando da Fonseca; DELLORE, Luiz; OLIVEIRA JR., Zulmar Duarte. Processo de conhecimento e cumprimento de sentença - comentários ao CPC de 2015. São Paulo: Método, 2016, p. 747. No mesmo sentido é o enunciado n. 58 do FPPC, segundo o qual "As decisões de inconstitucionalidade a que se referem os art. $525, \S \S 12$ e 13 e art. $535 \S \S 5^{\circ}$ e $6^{\circ}$ devem ser proferidas pelo plenário do STF”.
} 
em trâmite o processo de conhecimento e a possibilidade de alegação de não observância de precedente obrigatório após o trânsito em julgado.

Importa relembrar que a formação da coisa julgada é vista como um mecanismo de proteção da segurança jurídica que deve proteger a decisão acobertada por essa eficácia. Ainda assim, o sistema processual admite o ataque à coisa julgada pela violação a precedente obrigatório, mas mantém a "proteção" à não consideração de precedente obrigatório quando ainda em trâmite o processo, limitando a alegação de embargos de declaração pela omissão indireta, permitida apenas no caso de não observância de precedente advindo de casos repetitivos ou incidente de assunção de competência.

\section{A interpretação ampliativa das hipóteses de cabimento de embargos de} declaração por omissão indireta a precedentes obrigatórios

Como visto anteriormente, apenas em hipóteses bastante restritas, o texto expresso do CPC permite a oposição de embargos de declaração quando há omissão na análise de precedente obrigatório não suscitado pelas partes. Esse cabimento dos embargos de declaração por omissão indireta tem sido justificado, pela doutrina, a partir do dever de autorreferência como um dever de fundamentação específico, ${ }^{22}$ que consiste na imposição de que os juízes decidam sempre levando em consideração os precedentes pertinentes à questão jurídica enfrentada, ${ }^{23}$ em especial, os precedentes obrigatórios.

Tal possibilidade de utilização dos embargos de declaração não objetiva incrementar o princípio do contraditório efetivo - até porque irrelevante a prévia manifestação das partes -, mas relacionada a "uma responsabilidade para com a sociedade e o ordenamento jurídico, devendo o julgador oferecer resposta pelo seu desvio de solução que a priori seria a esperada, conforme os padrões decisões fixados". Assim, é uma regra relacionada aos deveres de integridade e coerência dos juízes e tribunais nos termos do art. 926 do CPC. ${ }^{24}$

\footnotetext{
${ }^{22}$ MACÊDO, Lucas Buril de. Precedentes judiciais e o direito processual civil. $2^{\mathrm{a}}$ ed. Salvador: Juspodivm, 2017 , p. 507.

${ }^{23}$ PEIXOTO, Ravi. Superação do precedente e segurança jurídica. $4^{\mathrm{a}}$ ed. Salvador: Juspodivm, 2019, p. 174.

${ }^{24}$ MACÊDO, Lucas Buril de. Precedentes judiciais e o direito processual civil... cit., p. 507.
} 
Essa constatação apenas reforça a situação de incompatibilidade com a sistemática do CPC, restringindo o cabimento dos embargos de declaração pela omissão indireta.

Como visto, existem diversos argumentos que a demonstram:

i) ampla possibilidade de alegação de fatos supervenientes de ofício, que, não analisados de ofício, podem ser suscitados por meio de embargos de declaração. Curiosamente, essa mesma amplitude não é verificada em relação aos precedentes obrigatórios surgidos no decorrer do processo, quando, em geral, há uma valorização da atuação do juiz em relação a aplicação do direito, cabendo às partes a alegação dos fatos;

ii) a legislação processual admite amplamente a utilização de precedentes obrigatórios para a alegação de não observância de precedentes obrigatórios mesmo após o trânsito em julgado, bem mais ampla do que o cabimento dos embargos de declaração

iii) se o cabimento dos embargos de declaração por omissão indireta ocorrer por decorrência do dever de autorreferência, simplesmente não faz sentido que essa exigência esteja presente tão apenas para casos repetitivos e incidente de assunção de competência. $O$ dever de autorreferência, ao menos, deve ser exigido igualmente de todos os precedentes obrigatórios, sendo um contrassenso que se o exija apenas a alguma das espécies de precedentes.

Como se verifica do próprio regime dos precedentes repetitivos e incidente de assunção de competência, não há nenhuma particularidade que os destaque dos demais. Mesmo que se utilize de uma diferenciação dentro do próprio regime de precedentes, como, por exemplo, o faz Teresa Arruda Alvim, dividindo-os em vinculatividade forte, média e fraca, ${ }^{25}$ o texto normativo não tem lógica. Isso porque, tanto a súmula vinculante, como os precedentes da ação do controle concentrado de constitucionalidade possuem o regime de vinculatividade forte enquanto o precedente decorrente do incidente de assunção de competência possui um regime de vinculatividade média.

\footnotetext{
25 Segundo a autora, a divisão ocorre da seguinte maneira: i) a vinculatividade forte ocorre quando há instrumento processual específico para o controle da aplicação do precedente, no caso, a reclamação, cabível para a súmula vinculante, ações do controle concentrado e processos repetitivos; ii) a vinculatividade média existe quando o desrespeito ao precedente pode ser corrigido pela via recursal e a presença do precedente pode ser fundamento de abreviação do processo, permitindo, por exemplo a sentença de improcedência liminar, como ocorre com o IAC, a dispensa do reexame necessário etc e iii) a vinculatividade fraca, quando é apenas cultural. (ALVIM, Teresa Arruda. Modulação na alteração da jurisprudência firme ou de precedentes vinculantes. São Paulo: RT, 2019, p. 98-100).
} 
Há julgados dos tribunais superiores que permitem a utilização dos embargos de declaração para a alegação de precedentes obrigatórios supervenientes para além das hipóteses legais.

Em recente decisão, o STF acolheu embargos de declaração para dar provimento a agravo regimental e julgar procedente reclamação, de forma a cassar o acórdão impugnado, com determinação para que a autoridade reclamada observasse o entendimento fixado no Tema 725 da repercussão geral (RE 958.252, rel. Min. Luiz Fux) e ADPF 324 (rel. Min. Roberto Barroso), que se referem ao tema da terceirização. ${ }^{26}$ Note-se que nem os precedentes da repercussão geral e nem os decorrentes das ações do controle concentrado do STF são abrangidos pelo art. 1.022, parágrafo único, I, do CPC.

Há, inclusive, uma passagem interessante da discussão entre os ministros que concerne justamente a discussão do cabimento dos embargos de declaração para reajustar a decisão embargada à nova jurisprudência do tribunal. Nesse ponto, concluiu o ministro Luís Roberto Barroso que a partir de agora seria a hipótese de se utilizar dessa espécie recursal para a readequação da decisão a novas decisões do plenário do STF.

O STJ admitiu, ao menos em tese, a possibilidade de utilização dos embargos de declaração para a alegação de precedente vinculante superveniente do STF, em atenção à instrumentalidade das formas, à garantia da celeridade e a eficácia da prestação jurisdicional. $^{27}$

Ainda mais recentemente, ocorreu uma divergência no STJ, nas turmas com competência criminal, sobre o cabimento dos embargos de declaração para adequação da decisão da Corte à nova jurisprudência do STF acerca da aptidão da sentença condenatória para interromper o prazo prescricional, que é diametralmente oposto ao entendimento consolidado do STJ. Por outro lado, a $5^{\text {a }}$ Turma rejeitou essa aptidão dos embargos de declaração, ${ }^{28}$ a $6^{\text {a }}$ Turma permitiu a reforma do julgado. ${ }^{29}$

\footnotetext{
${ }^{26}$ STF, $1^{a}$ T., Rcl 15.724 AgR-ED/PR, rel. orig. Min. Rosa Weber, red. p/ o ac. Min. Alexandre de Moraes, j. 05/05/2020, info. n. 976. Essa possibilidade já havia sido admitida pelo STF, no âmbito do processo penal, em que admitida a utilização dos embargos de declaração para a alegação de alteração da jurisprudência do tribunal no que se refere à progressão do regime prisional no caso dos crimes hediondos (STF, $2^{\mathrm{a}}$ T., HC 85.963 ED, Rel. Celso de Mello, j. 03/10/2006, DJ 27/10/2006).

${ }^{27}$ STJ, $1^{\text {a }}$ T., EDcl no REsp 1.665.599/RS, Rel. Min. Napoleão Nunes Maia Filho, j. 18/05/2020, DJe $25 / 05 / 2020$.

${ }^{28}$ STJ, $5^{\text {a }}$ T., EDcl no AgInt no PExt no HC 484074/SP, Rel. Min, Sebastião Reis Júnior, j. 30/06/2020, acórdão ainda não publicado.

${ }^{29}$ STJ, $6^{a}$ T., EDcl no AgRg no RHC 109.530/RJ, Rel. Min. Ribeiro Dantas, j. 26/05/2020, DJe 01/06/2020.
} 
Uma situação curiosa, referente ao julgado do STJ que admitiu a alteração da decisão por meio dos embargos declaratórios é a de que o novo precedente sequer fora alegado pelas partes. Foi suscitado de ofício pelos julgadores, tendo em vista que o julgamento do STF ocorreu após a oposição dos embargos de declaração. Nessa situação, uma crítica deve ser feita ao acórdão, pois deveria ter ocorrido a intimação das partes para que pudessem se manifestar sobre a aplicação ou não do precedente advindo do STF.

A interpretação que se propõe para a alegação de omissão externa no que se refere aos precedentes é no sentido de ampliar as hipóteses de cabimento do art. 1.022, parágrafo único, I, do CPC, permitindo sua utilização quando ausente manifestação sobre algum dos precedentes listados no art. 927 do CPC. ${ }^{30}$

Trata-se de interpretação ajustadora horizontal, ${ }^{31}$ substituindo uma interpretação literal, baseada na obrigação de autoreferrência do Poder Judiciário, constante de uma norma fundamental do CPC prevista no art. 926 do CPC. Para além disso, com essa interpretação, há uma maior harmonização com outros dispositivos do CPC que permitem a ampla utilização dos embargos de declaração no caso de omissão de fatos supervenientes, permitem a alegação desses precedentes mesmo após o trânsito em julgado e também permitem sua utilização para diversos temas não analisados pelo juiz e não suscitados pelas partes.

Da mesma forma, a interpretação ampliativa do texto normativo também densifica o princípio da economia processual, evitando a necessidade de utilização posterior de ação rescisória ou da impugnação ao cumprimento de sentença. Como bem observou Carlos Roberto Barbosa Moreira, há uma tendência dos tribunais superiores em admitir os embargos de declaração para além das hipóteses legais, quando as providências são tidas como vantajosas sob o prisma da economia processual, a exemplo de hipótese em que se

\footnotetext{
${ }^{30}$ Com a mesma conclusão: BARBOSA MOREIRA, Carlos Roberto. Os novos embargos de declaração. Revista de Processo, n. 287, jan.-2019, p. 285; CUNHA, Leonardo Carneiro da; DIDIER JR., Fredie. Curso de direito processual civil... cit., p. 311; BUENO, Cassio Scarpinella. Curso sistematizado de direito processual civil. $8^{a}$ ed. São Paulo: Saraiva, 2019, versão digital, parte 3, capítulo 5, item 2; PEIXOTO, Marco Aurélio; BECKER, Rodrigo. Os embargos de declaração podem adequar o julgado a um precedente superveniente? Disponível em: https://www.jota.info/opiniao-e-analise/colunas/coluna-cpc-nos-tribunais/osembargos-de-declaracao-podem-adequar-o-julgado-a-um-precedente-superveniente-24072020, acessado em 25/07/2020.

${ }^{31}$ CHIASSONI, Pierluigi. Técnicas de interpretación jurídica. Breviario para juristas. Trad. Pau Luque Sánchez e Maribel Narváez Mora. Madri: Marcial Pons, 2011, p. 152.
} 
admitiu esse recurso para conhecer de recurso especial tido por intempestivo, como forma de evitar uma futura ação rescisória. ${ }^{32}$

Naturalmente, a aptidão de o precedente suscitado alterar o resultado total ou parcial do julgamento dependerá da devida demonstração, pela parte, de que o precedente é aplicável ao caso concreto. Para além disso, ainda será relevante identificar se, tendo o precedente surgido no decorrer do processo, e abarcando, em tese, a situação concreta, não ocorreu alguma alteração da sua eficácia temporal. Isso ocorre porque é possível que, na modulação da eficácia temporal do novo precedente, a situação jurídica concreta tenha sido excluída do âmbito de eficácia do novo posicionamento jurisprudencial.

\section{Conclusão}

A proposta do texto foi bastante simples: analisar o cabimento dos embargos de declaração por omissão indireta no que se refere aos precedentes obrigatórios. O art. 1.022, parágrafo único, I, do CPC, propõe um cabimento bastante restritivo dessa espécie de omissão, limitando-a tão apenas nos casos dos precedentes oriundos de recursos repetitivos e incidente de assunção de competência, considerados precedentes obrigatórios nos termos do art. 927, III, do CPC.

Ocorre que, como visto, essa previsão normativa está em desacordo com a sistemática do CPC, que, além de ser mais abrangente para a alegação de omissões indiretas para temas que, em geral, há uma prevalência da atuação das partes, como ocorre nos fatos supervenientes, permite a utilização desses mesmos precedentes após o trânsito em julgado da decisão. Mais ainda, ignora a importância da manutenção das decisões em acordo com o entendimento dos precedentes obrigatórios, sendo uma decorrência do dever de autorreferência a imposição de que os juízes, no momento da decisão, levem em consideração os precedentes obrigatórios.

Assim, o texto propõe uma interpretação ampliativa do art. 1.022, parágrafo único, I, do CPC para permitir o cabimento dos embargos de declaração por omissão indireta

\footnotetext{
${ }^{32}$ BARBOSA MOREIRA, Carlos Roberto. Os novos embargos de declaração... cit., p. 283. Com entendimento semelhante: BONDIOLI, Luís Guilherme Aimar. Comentários ao código de processo civil... cit., item 144.
} 
em todas as hipóteses em que a decisão deixe de levar em consideração precedente obrigatório (art. 927, CPC).

\section{REFERÊNCIAS}

ADEODATO, João Maurício. A retórica constitucional: sobre tolerância, direitos humanos e outros fundamentos éticos do direito positivo. $2^{\text {a }}$ ed. São Paulo: Saraiva, 2010.

ALVIM, Teresa Arruda. Modulação na alteração da jurisprudência firme ou de precedentes vinculantes. São Paulo: RT, 2019.

ÁVILA, Humberto. Segurança jurídica. Malheiros: 2011 Teoria dos princípios. 12a ed. São Paulo: Malheiros, 2011.

BONDIOLI, Luís Guilherme Aimar. Comentários ao código de processo civil. $2^{\mathrm{a}}$ ed. São Paulo: Saraiva, 2017, v. XX, versão digital.

CÂMARA, Alexandre Freitas. Será o fim da categoria "Condição da Ação"? Uma resposta a Fredie Didier Junior. Revista de Processo, n. 197, jul.-2011.

CHIASSONI, Pierluigi. Técnicas de interpretación jurídica. Breviario para juristas. Trad. Pau Luque Sánchez e Maribel Narváez Mora. Madri: Marcial Pons, 2011.

COSTA, Adriano Soares da. Teoria da incidência da norma jurídica. Belo Horizonte: Del Rey, 2003.

CRAMER, Ronaldo. Ação rescisória por violação da norma jurídica. $2^{\mathrm{a}}$ ed. Salvador: Juspodivm, 2012

CUNHA, Leonardo Carneiro da. Comentários ao art. 493. In: DIDIER JR., Fredie; TALAMINI, Eduardo; WAMBIER, Teresa Arruda Alvim; DANTAS, Bruno (coords). Breves comentários ao Novo Código de Processo Civil. São Paulo: RT, 2015. . Será o fim da categoria condições da ação? Uma intromissão no debate travado entre Fredie Didier Jr. e Alexandre Freitas Câmara. Revista de Processo, n. 198, ago.2011.

CUNHA, Leonardo Carneiro da; DIDIER JR., Fredie. Curso de direito processual civil. 16 ed. Salvador: Juspodivm, 2019, v. 3.

GOMETZ, Gianmarco. La certeza giuridica come prevedibilità. Torino: Giappichelli Editore, 2005. 
KELSEN, Hans. Teoria pura do direito. Trad. de João Baptista Machado. São Paulo: Martins Fontes, 2011.

MACÊDO, Lucas Buril de. Precedentes judiciais e o direito processual civil. $2^{\mathrm{a}}$ ed. Salvador: Juspodivm, 2017.

MAZZEI, Rodrigo. Embargos de declaração e a omissão indireta (matérias que devem ser resolvidas de ofício, independentemente de arguição prévia pelo interessado). Revista Forense. Rio de Janeiro: Forense, v. 399, set./out.-2008.

MITIDIERO, Daniel; MARINONI, Luiz Guilherme. Ação rescisória. São Paulo: RT, 2017. MOREIRA, José Carlos Barbosa. Comentários ao código de processo civil. 14 ${ }^{\mathrm{a}} \mathrm{ed}$. Rio de Janeiro: Forense, 2008, v. V.

MÜLLER, Friedrich. Metodologia do direito constitucional. $4^{\mathrm{a}}$ ed. Trad. de Peter Naumann. São Paulo: RT, 2010.

NEVES, Marcelo. Entre Hidra e Hércules: princípios e regras constitucionais. São Paulo: Martins Fontes, 2013.

PEIXOTO, Marco Aurélio; BECKER, Rodrigo. Os embargos de declaração podem adequar o julgado a um precedente superveniente? Disponível em: https://www.jota.info/opiniao-e-analise/colunas/coluna-cpc-nos-tribunais/osembargos-de-declaracao-podem-adequar-o-julgado-a-um-precedente-superveniente24072020, acessado em 25/07/2020.

PEIXOTO, Ravi. Superação do precedente e segurança jurídica. $4^{\mathrm{a}}$ ed. Salvador: Juspodivm, 2019.

PEIXOTO, Ravi; DIDIER JR., Fredie. O art. 489, $§ 1^{\circ}$, do CPC e a sua incidência na postulação dos sujeitos processuais - um precedente do STJ. In: ALVIM, Teresa Arruda; CIANCI, Mirna; DELFINO, Lucio. (Org.). Novo CPC aplicado visto por processualistas. São Paulo: Revista dos Tribunais, 2017.

ROQUE, Andre Vasconcelos. Comentários ao art. 525. IN: ROQUE, Andre Vasconcelos; GAJARDONI, Fernando da Fonseca; DELLORE, Luiz; OLIVEIRA JR., Zulmar Duarte. Processo de conhecimento e cumprimento de sentença-comentários ao CPC de 2015. São Paulo: Método, 2016. 
STRECK, Lenio Luiz. Diferença (ontológica) entre texto e norma: afastando o fantasma do relativismo. In: TORRES, Heleno Taveira. (coord). Direito e poder: nas instituições e nos valores do público e do privado contemporâneo. Barueri: Manole, 2005.

. O que é isto - decido conforme minha consciência? Porto Alegre: Livraria do Advogado, 2010

WAMBIER, Teresa Arruda Alvim. Omissão judicial e embargos de declaração. São Paulo: RT, 2005.

WARAT, Luis Alberto. Introdução geral ao direito - o direito não estudado pela teoria jurídica moderna. Porto Alegre: SAFE, 1997, v. III. 